\title{
Exacerbation of recalcitrant cutaneous sarcoidosis with adalimumab - a paradoxical effect? A case report
}

\author{
Agravamento de lesões refratárias de sarcoidose cutânea com \\ adalimumab- um efeito paradoxal? Relato de um caso
}

Guida Santos ${ }^{1}$
Alexandre Miguel Bruno Lopes João 3

\begin{abstract}
The paradoxical adverse effects of tumor necrosis factor-alpha (TNF-alpha) antagonists have been described frequently as a result of the widespread use of these drugs. Among the TNF-alpha blocking agents, few reports exist relating the use of adalimumab in cutaneous sarcoidosis, although all of them show good results. More recently, sarcoidosis onsets have been reported with various TNF-alpha inhibitors. The current case is, to our knowledge, the first to describe the exacerbation of cutaneous lesions of sarcoidosis treated with adalimumab.
\end{abstract}

Keywords: Biological agents; Biological treatment; Sarcoidosis; Tumor necrosis factor-alpha

Resumo: Os efeitos paradoxais dos anti-TNF-alpha têm sido cada vez mais descritos com a utilização mais ampla dessas drogas. Entre os TNF-alpha, registam-se poucos casos com a utilização de adalimumab no tratamento da sarcoidose cutânea, sendo que todos eles apresentam bons resultados. Têm sido descritos, mais recentemente, casos de sarcoidose induzidos por vários anti-TNF-alpha. O presente caso é, até à data, o primeiro a descrever a exacerbação de lesões cutâneas de sarcoidose tratadas com adalimumab.

Palavras-chave: Agentes biológicos; Fator de necrose tumoral alfa; Sarcoidose; Tratamento biológico

\section{INTRODUCTION}

Sarcoidosis is a multisystemic inflammatory disorder of unknown cause ${ }^{1,2}$ and for which there is no universally accepted treatment. Systemic agents such as corticosteroids are often effective, and steroid-sparing agents such as methotrexate, azathioprine, antimalarial drugs, pentoxifylline, allopurinol and thalidomide have been shown to be beneficial for selected patients, but their use is limited due to significant toxic effects of their own and inconsistencies in efficacy. ${ }^{1}$ Refractory systemic and cutaneous sarcoidosis has been shown to improve with inhibition of TNF$\alpha$. Few reports are available with adalimumab in the treatment of cutaneous sarcoidosis. With the wide- spread use of TNF- $\alpha$ antagonists, paradoxical adverse effects have been described more frequently with these drugs and are defined as the onset or exacerbation of disorders that are usually improved by their administration. ${ }^{2,3}$ Psoriasis onset or exacerbation and sarcoid-like-granulomatosis onset has been more frequently reported with TNF- $\alpha$ inhibitors, but rare cases of exacerbation of cutaneous sarcoidosis have been documented with them. ${ }^{3,4}$

The authors describe a clinical case of cutaneous sarcoidosis in which the treatment with adalimumab was not only ineffective, but exacerbation of the disease was observed.

Received on 26.01.13.

Approved by the Advisory Board and accepted for publication on 28.04.2013.

* Work performed at the Department of Dermatology and Venereology of the Santo António dos Capuchos Hospital - Centro Hospitalar de Lisboa Central - Porto, Portugal.

Financial support: none.

Conflict of interests: none.

MD, Resident at the Dermatolovenereology Department of the Santo António dos Capuchos Hospital - Centro Hospitalar de Lisboa Central -Lisbon.

MD Consultant at São Bernardo Hospital - Centro Hospitalar de Setúbal, EPE - Setúbal, Portugal.

MD Consultant at Santo António dos Capuchos Hospital - Centro Hospitalar de Lisboa Central - Lisbon, Portugal.

(C)2013 by Anais Brasileiros de Dermatologia 


\section{CASE REPORT}

A 50-year-old female was observed due to erythematous, infiltrated, sometimes ulcerated plaques, on the frontal and left preauricular areas lasting for 2 years. (Figure 1). The patient had high blood pressure and was treated with bisoprolol $5 \mathrm{mg} /$ day.

The plaque on the left preauricular area was biopsied. Biopsy was performed showing dermal granuloma, without central caseous necrosis and numerous Langhans multinucleated giant cells. (Figure 2) Acid-fast bacteria stains were negative as well as tissue cultures for mycobacteria, bacteria and fungi. Infectious etiology was excluded and the diagnosis of cutaneous sarcoidosis was made. Except for cutaneous involvement, the patient was in good health with no systemic symptoms. Further evaluations included a complete blood cell count and complete metabolic panel, both of which revealed no significant abnormal findings. C-reactive-protein, angiotensin-converting-enzyme (ACE) and calcium were in the normal range. Further investigation for systemic involvement was negative. Local therapy with topical and intralesional corticosteroids (momethasone furoate and clobetasol propionate creams; betamethasone dipropionate and betamethasone phosphate sodium aqueous suspension, successively) and topical tacrolimus failed. Hydroxychloroquine sulfate (400 mg daily), pentoxifylline (400 mg daily), methylprednisolone (up to 25 mg daily), azathioprine (100 mg daily) and methotrexate (up to $27,5 \mathrm{mg}$ / week until cumulative dosis of 733 $\mathrm{mg}$ ) produced no significant effect.
Long-term treatment with systemic corticosteroids, azathioprine or methotrexate was felt to be unwarranted because of the risk of serious long-term sequelae. Treatment with adalimumab was proposed as an alternative to treatment with methotrexate.

Tuberculin skin test was performed before initiating the biological agent and revealed a 1.1 millimeter papule. Therefore isoniazid (300mg/day) was started.

Methotrexate was gradually tapered to 7.5 $\mathrm{mg} /$ week and methylprednisolone $(4 \mathrm{mg} /$ day) and then stopped. Adalimumab (40 $\mathrm{mg}$ subcutaneously at week 1, 3 and 5) was started two months after the start of isoniazid. Adalimumab was then suspended (after the third injection) because the lesions became more erythematous, infiltrated, ulcerated and associated to

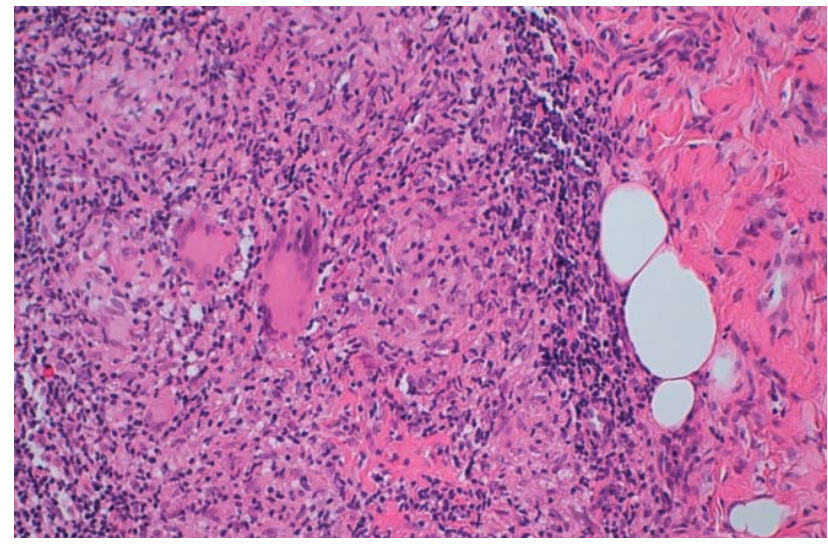

FIGURE 2: Histopathology H\&Ex200. Sarcoid granuloma in the reticular dermis (with epithelioid hystiocytes, Langhans giant cells, without necrosis and some peripheral lymphocytes)
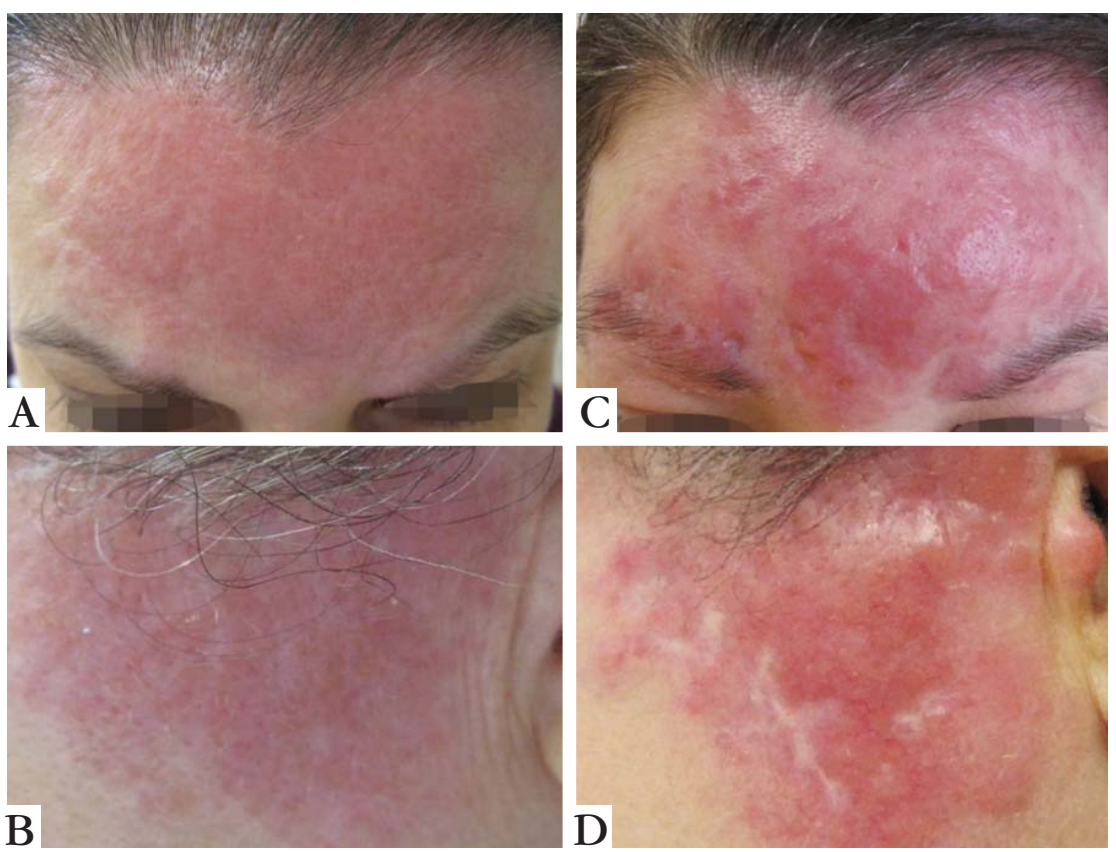

Figure 1: (A) Plaque of sarcoidosis on the frontal area and (B) on the left preauricular area just before adalimumab; (C) Plaque on the frontal area and (D) on the left preauricular area after 3 injections of adalimumab 
retroauricular adenopathies (Figure 1). Shortly after suspension, the lesions improved.

\section{DISCUSSION}

Effective management of patients with sarcoidosis remains problematic. Recent clinical trials of TNF- $\alpha$ inhibitors for the treatment of sarcoidosis have reported mixed results. ${ }^{2}$ Anti-TNF- $\alpha$ blockers appear to be effective in the manifestations of refractory sarcoidosis but they are not approved by the FDA for the treatment of sarcoidosis. A survey of the available literature revealed only 6 articles which report treatment of cutaneous sarcoidosis with adalimumab and all these reports revealed good results. ${ }^{5-10}$ These reports showed adalimumab efficacy in different clinical settings, including leg ulcer, cutaneous nodules and plaques on the face and lupus pernio. Three patients were treated previously with another anti-TNF- $\alpha$ (1 etanercept and 2 infliximab). ${ }^{5,6,7}$ Switching to another blocker resulted in clinical improvement, which indicates that the granulomatosis occurrence is not predictable. The pathogenesis of worsening of sarcoidosis as the induction of sarcoid-like granuloma under these blockers is still not well understood. Disease heterogeneity and differences in pharmacokinetics, pharmacodynamics and mechanisms of action may account for these effects.

A growing number of reports concerning paradoxical adverse events due to TNF-alpha antagonists have been published. ${ }^{2,4}$ Most of the information available comes from isolated clinics cases or small series of cases.

There are more than 42 paradoxical effects of sarcoidoid-like granuloma during anti-TNF- $\alpha$ therapy. ${ }^{3}$ Non-exclusively cutaneous involvement was more frequent. The suggested role of TNF-alpha in the genesis of granulomas has led researchers to investigate anti-TNF-alpha treatment of granuloma formation diseases.

Genetic variations of the TNF- $\alpha$ gene is emerging as an important factor in determining sarcoidosis predisposition and course. Polymorphism of the genes that mediate cytokine production may be associated with distinct immune pathways, but implications of TNF-alpha genes and the predisposition to resistance to therapy are still not known.

Only a fraction of the treated population normally responds to biologics, and clinical markers for the prediction of the efficacy are seldom available. ${ }^{2}$

In our case, although methylprednisolone was stopped and methotrexate slightly tapered, this suggests a possible triggering role of the anti-TNF- $\alpha$ therapy because of the prompt clinical improvement after discontinuation of adalimumab.

Paradoxical effects of TNF-alpha blockers in sarcoidosis are based on the supposed efficacy of these agents in this disease. ${ }^{2}$ The worsening of the patient's lesions with adalimumab contributes to the reports of paradoxical adverse events during TNF- $\alpha$ blocking agents.

To our knowledge, our case is the first paradoxical exacerbation with adalimumab and the third case to describe worsening of pre-existing cutaneous sarcoidosis with an anti-TNF-alpha antagonist. A better understanding of the pathogenic role of TNF- $\alpha$ in sarcoidosis and of its therapeutic blocking action will help to explain this phenomenon. The development of pharmacogenomics to identify responders or nonresponders is highly desirable. ${ }^{2} \square$

\section{REFERENCES}

1. Daldon PE, Arruda LH. Noninfectious granulomas: sarcoidosis. An Bras Dermatol. 2007:82:559-71.

2. Viguier M, Richette P, Bachelez H, Wendling D, Aubin F. Paradoxical adverse effects of anti-TNF-alpha treatment: onset or exacerbation of cutaneous disorders. Expert Rev Clin Immunol. 2009;5:421-31.

3. Javot L, Tala S, Scala-Bertola J, Massy N, Trenque T, Baldin B, et al. Sarcoïdosis and anti-TNF: a paradoxical class effect? Analysis of the French Pharmacovigilance System database and literature review. Therapie. 2011;66:149-54.

4. Dhaille F, Viseux V, Caudron A, Dadban A, Tribout C, Boumier P, et al Cutaneous sarcoidosis occurring during anti-TNF-alpha treatment: report of two cases. Dermatology. 2010;220:234-7.

5. Callejas-Rubio JL, López-Pérez L, Ortego-Centeno N. Tumor necrosis factor-alpha inhibitor treatment for sarcoidosis. Ther Clin Risk Manag. 2008;4:1305-13.

6. Thielen AM, Barde C, Saurat JH, Laffitte E. Refractory chronic cutaneous sarcoidosis responsive to dose escalation of TNF-alpha antagonists. Dermatology. 2009;219:59-62.

7. Field S, Regan AO, Sheahan K, Collins P. Recalcitrant cutaneous sarcoidosis responding to adalimumab but not to etanercept. Clin Exp Dermatol. 2010;35:795-6.
8. Judson MA. Successful treatment of lupus pernio with adalimumab. Arch Dermatol. 2011;147:1332-3.

9. Kaiser CA, Cozzio A, Hofbauer GF, Kamarashev J, French LE, Navarini AA. Disfiguring annular sarcoidosis improved by adalimumab. Case Rep Dermatol. 2011;3:103-6.

10. Philips MA, Lynch J, Azmi FH. Ulcerative cutaneous sarcoidosis responding to adalimumab. J Am Acad Dermatol. 2005;53:917.

MAILING ADDRESS:
Guida Santos,
Department of Dermatology and Venereology,
Hospital Santo António dos Capuchos,
Alameda Santo António dos Capuchos,
1169-050 - Lisbon
Portugal
E-mail: guidadossantos@gmail.com

MAILING ADDRESS:

Guida Santos,

Department of Dermatology and Venereology, Hospital Santo António dos Capuchos,

Alameda Santo António dos Capuchos,

Portugal

E-mail: guidadossantos@gmail.com

How to cite this article: Santos G, Sousa LE, João AMBL. Exacerbation of recalcitrant cutaneous sarcoidosis with adalimumab - a paradoxical effect? A case report. An Bras Dermatol. 2013;88(6 Suppl 1):S26-8. 